\title{
GROUPS OF COMPANIES AND THE TRANSACTIONS IN BETWEEN: A QUALITATIVE ANALYSIS OF THE IN INTERNATIONAL AND NATIONAL LEGISLATION
}

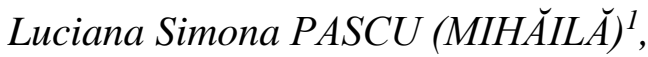 \\ Mihaela MORAR ${ }^{2}$ \\ Cristian PARASCHIV
}

\begin{abstract}
The presence of the groups of companies in most sectors of activity, their significant weight in the world trade in goods and services and the importance of the transactions between them are the factors that have determined us to choose this research theme. In recent years, the formation of groups of societies has been a major phenomenon and, due to this, we consider it desirable to pay special attention to the legislation governing the work of these groups.n Starting from this hypothesis, we intend to analyze the degree of similarity between the specific regulations in this field in Romania and the international standards in this research. In order to perform this qualitative analysis, we used the Jaccard similarity coefficient.
\end{abstract}

Key words: group of companies, affiliatedparties, related-party transactions, Jaccard index

\section{JEL codes: G34, G38, M48}

\section{Introduction}

Nowadays, the group of companies is representing a reality at least as important as the enterprise. These legal entities have been imposed as a negligible economic reality. In modern society, there is no sector of activity in which the multinational groups with a global or even globalizing tendency have not speared. (Joffre, 1994, pag.72)

Besides the economic development and the development of the financial market, the desire to expand and to enter new markets was another reason for the emergence of multinational groups. The unquestionable reality, the existence of groups of national and multinational societies brings about mutations and consequences in economic, legal, social, fiscal and, last but not least, accounting. Due to the fact that in recent years the formation of groups of societies has been a big phenomenon, the tax authorities at the global level have begun to pay special attention to the activities carried out within the groups. The core of these concerns is how the results obtained within a group are divided among the member companies of the group.

The Organization for Economic Cooperation and Development has estimated several years ago that, as compared to the total of transactions worldwide, those among affiliated entities represent no less than $65 \%$; a significant figure that led to the need to regulate these intra-group relationships. (OECD, 2014)

The main objective of this research is to perform a qualitative analysis of the groups of companies and the transactions between them, referring to the national and international regulations.

In order to achieve the objective we have documented from national and international legislation, as well as articles on the subject, published in journals from the mainstream of publications.

In the paper we presented the information from general to private (deductive method). Thus, in the first part we presented the groups of companies, specifying the issues related to the transactions

\footnotetext{
${ }^{1}$ PhD student, “1 Decembrie 1918” University Alba Iulia, e-mail: luciana.pascu@uab.ro,

${ }^{2}$ Babes-Bolyai University, Cluj-Napoca, Romania, E-mail: m_morar@yahoo.com

${ }^{3}$ Universitatea „Lucian Blaga” din Sibiu, email:cristi.paraschiv08@yahoo.com

DOI: 10.29302/oeconomica.2020.22.1.5
} 
between them and the specific regulations at national and international level, and in the second part we calculated, with the help of the Jaccard index, the degree of similarity between the national legislation in this field and international regulations.

\section{Groups of companies and importance of intra-group transactions}

Groups of societies, ubiquitous in all sectors of activity, have imposed themselves as a difficult economic reality to neglect, although legally they are not considered as a legal reality. (Tiron Tudor A. \&al, 2005, pag. 290)

In the literature, we find the transactions between affiliated persons analyzed in the light of three theories: efficiency, conflict of interest, contingency theory.

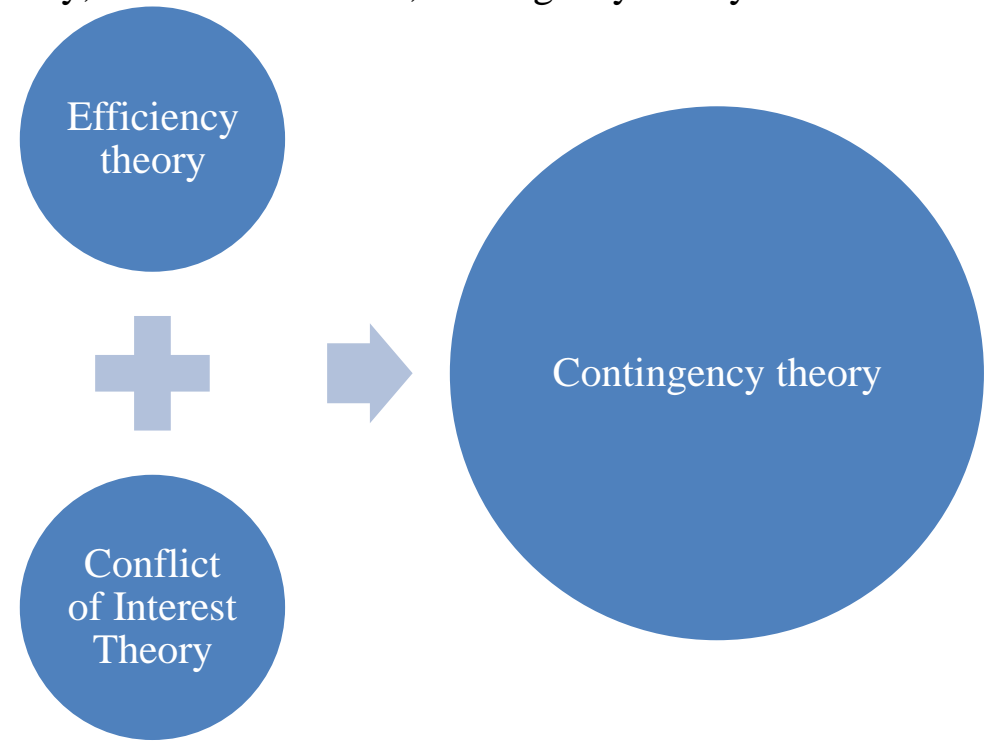

Figure 1: The connection between the three theories

Source: Author's projection

\section{a) Efficiency theory}

From the perspective of economic efficiency theory, affiliate-related transactions are beneficial operations that support the economic needs of the entities in which they are conducted.

In the literature, among the most approached themes that analyze this kind of transactions, based on the theory of efficiency, there are:

$>$ reduction of transaction costs; (Coase, 1937, Williamson, 1985, Fan \& Goyal, 2006)

$>$ creating a market that benefits the group; (Khanna\& Palepu, 1997)

$>$ investment in emerging markets; ( Fisman\& Khanna, 2004)

$>$ transfer of technologies and other resources (Chang \& Hong, 2000; Moscariello, 2007)

Analyzing the literature, it has been found that among the main benefits that are considered to be brought about by intra-group transactions conducted in good faith:

- reduction of transaction costs due to vertical or horizontal integration, which has the effect of maximizing net profit and increasing the operational profitability and competitiveness of the group as a whole;

- increasing the return on assets;

- means of allocating internal resources;

- optimal allocation of internal resources;

- obtaining economies of scale due to the internalisation of markets;

- reducing the risks associated with foreign markets;

- reducing the time required to run some transactions;

- reduction of tax burden. 
Gordon et al. (2007) illustrates the idea that many corporations have a large volume of intra-group transactions that do not involve financial or accounting fraud. However, due to the fact that such transactions are often used fraudulently or incorrectly, their positive effects have become underestimated or even overlooked. (Chen et al., 2009)

\section{b)Conflict of Interest Theory}

According to this theory, each interest group in an entity (each agent) acts to achieve personal interest and maximize its own gain. Conflict occurs when the reis a discrepancy between the principal's interest (shareholder, associate, manager, entrepreneur, generally anyleader) and that of the agent (administrator, employee, subordinate). The main supporter of this theory is the well-known American economist Milton Friedman, whose primary responsibility is to use resources to maximize long-term profits.

Managers are shareholders' agents and have an obligation to act to meet their interests, and the issue of conflict-of-interest theory is essential in corporate governance. For dispersed shareholders, this theory attempts to explain "how shareholders' and managers' interests can be aligned, and for those with a concentrated shareholders' structure," how the interests of major shareholders and minority shareholders can be aligned. The theory of conflict of interest stems from utilitarian theory, according to which the result of an action can be considered ethical if it produces more good than harm. In the specialty studies, the conflict of interest theory is also used as the agent (or agency) theory.

In the literature, among the most approached themes that analyze transactions between affiliated parties based on the conflict of interest theory:

- $\quad$ corrupt corporate governance: undermining the functions of non-executive directors;

- $\quad$ managing financial results ("earnings management");

- $\quad$ embezzlement of funds (tunneling);

- $\quad$ hiring relatives in family businesses;

- $\quad$ fraudulent financial statements.

The classification by Nekhili\&Cherif (2011, p.296) notes the following as the most frequently discussed topics:

- $\quad$ the correlation between affiliated transactions and the manipulation of financial results;

- capital diversion through the transfer of capital from the high growth potential to the small potential;

- welfare transfer from minority shareholders to the majority.

Nekhili\&Cherif's research reveals that research on the opportunism of affiliate transactions has as a basis both the emerging markets that are recognized for governance deficits as well as countries in Europe or even America.

Analyzing the literature, it was found that, althoughcross-party transactions may have beneficial effects for the group of companies and, broadly, for the society as a whole, however, when used for opportunistic purposes, their effects maybe deceptive, because this type of transaction has the ability to hidevariousstakes, such as:

- enriching one party to the detriment of the other party involved in the transaction expropriation of minority shareholders for the benefit of major shareholders, directors or directors;

- manipulation of financial results to achieve the desired level of operational performance: return on investment, return on sales, return on assets;

- an over estimation of earnings for various purposes, such as the right to issue new shares.

Transactions between affiliated parties conducted for opportunistic purposes typically take one of the following forms: goods sold or purchased at prices other than market values (excessive prices); loans obtained on preferential terms; assets sold for the benefit of major shareholders; fictitious sales. In view of the above, it is not unusual for affiliated parties to deal with transactions as some form of fraud.

On the other hand, the study by Gordon et al. (2007, p. 82) reveals that this kind of transactions are more common in fraud companies than in companies where no such practices exist. However, 
although isolated transactions between related parties are not an indicator of fraud, however, when fraud exists, they are one of the main reasons underlying it. In the same sense, the results of empirical research undertaken by Stauropoulus et al. (2011, p.161) shows that investors are more attentive to transactions between related parties involving assets than to those involving products (because the former are more susceptible to fraud) and Noronha et al. (2008, p. 367) are of the opinion that it is difficult to assess whether a particular decision was taken for the real purpose of the business or for other opportunistic purposes.

Summarizing the information presented above, the negative purposes of the related party transactions are: expropriation of minority shareholders, manipulation of financial results, asset diversion, overstatement of income.

\section{c)Contingency theory}

Generally, in the literature, affiliated party transactions are analyzed in an abstract theoretical framework, according to one of the two theories (efficiency or conflict of interest), the classification being based on certain particularities (the benefits - in the case of the first theory, the risk in the second case), without taking into account the specific organizational or institutional context that may affect the nature of the operations.

The possibility that the two theories coexist has never been taken in to account. Both theories show inconsistencies or deficiencies, and sometimes offer diametrically opposed interpretations. In the present reality, related party transactions can no longer be classified strictly in to one of the two categories, and requirements for monitoring and disclosure of information may not achieve the intended goals and involve greater complexity and cost-pertinent costs.

On the other hand, the approach to the idea that RPT always has effective transactions involves deregulation and may ignore certain risks associated with such transactions, which leadsto a decrease in investor confidence in the company. Therefore, the contingent approach is the solution.

Pizzo proposes a model for analyzing transactions between affiliated parties from a contingent perspective, intersecting the two theories that it builds on, on the one hand, from the study by Aguilera et al. (2008), and on the other hand, examining the causes and consequences of TFP that are influenced by: the organizational and social context, the complementarity / substitution of the corporate governance factors.

The contingency approach of the related party transactions proposed by Pizzo is based on contingency theory. According to Waweru et al., (2004, p.677), this theory was developed by Burns \& Stalker (1961) and Lawrence \&Lorsch (1967). The fundamental premise suggested by contingency theory is that there is no strategy that can be effective in any context.

Extrapolating the previous idea, we can say that the perspective that contingency theory offers on affiliated party transactions can be formulated as follows: RPT can no longer be categorized as either harmful transactions or beneficial transactions but their classification depends on the circumstances in which they occur economic constraints, global competition, technological development, size and organizational type, real interests of shareholders or managers, etc.)

In view of the above, in this paper, transactions between affiliated parties are addressed through the contingency theory. Specifically, TFPs are not characterized from the outset as efficient and harmful transactions, but they are considered to be clearly categorized into one of the two diametrically opposite categories only following a thorough analysis of all the circumstances in which these transactions are conducted.

\section{Jaccard index}

Comparative analysis of international law with national law on related parties using the

The Jaccard index, also known as the Intersection of the Union and the Jaccard similarity coefficient, is a statistic used to compare the likeness and diversity of sample sets. The Jaccard coefficient measures the similarity between the sets of finite samples and is defined as the intersection size divided by the sample size meeting: 


$$
J(A, B)=\frac{|A \cap B|}{|A \cup B|}=\frac{|A \cap B|}{|A|+|B|-|A \cap B|}
$$

The Jaccard distance, which measures the difference between the sample sets, is complementary to the Jaccard coefficient and is obtained by subtracting the Jaccard coefficient from 1 or by dividing the difference between the reunion and the intersection of two samples at their meeting:

$$
d_{J}(A, B)=1-J(A, B)=\frac{|A \cup B|-|A \cap B|}{|A \cup B|}
$$

In this regard, we will select several elements that normalize the affiliated parties' scope in accordance with IAS 24, and will examine their existence under Order 1802/2014 and Order 2844/2016, respectively their predecessors: OMFP 3055/2009 and OMFP 1286/2012. Subsequently, the Jaccard coefficients for each order will be calculated sequentially.

\begin{tabular}{|c|c|c|c|c|c|c|}
\hline No. & Element & $\begin{array}{c}\text { IAS } \\
24\end{array}$ & $\begin{array}{c}\text { OMFP } \\
1802 / 2014\end{array}$ & $\begin{array}{c}\text { OMFP } \\
2844 / 2016\end{array}$ & $\begin{array}{l}\text { OMFP } \\
3055 / 2009\end{array}$ & $\begin{array}{l}\text { OMFP } \\
1286 / 2012\end{array}$ \\
\hline I. & Keyelements & & & & & \\
\hline 1. & Affiliate part/ Relatedparties & 1 & 1 & 0 & 1 & 0 \\
\hline 2. & Transactionswithrelatedparties & 1 & 1 & 0 & 1 & 0 \\
\hline 3. & Key management personnel & 1 & 1 & 0 & 1 & 0 \\
\hline 4. & Close family members & 1 & 1 & 0 & 1 & 0 \\
\hline 5. & Compensation of employees & 1 & 1 & 0 & 1 & 0 \\
\hline 6. & Control & 1 & 1 & 0 & 0 & 0 \\
\hline 7. & Commun control & 1 & 1 & 0 & 0 & 0 \\
\hline 8. & Significant influence & 1 & 1 & 0 & 0 & 0 \\
\hline 9. & State & 1 & 1 & 1 & 1 & 0 \\
\hline 10. & Entity of public interest & 1 & 1 & 1 & 1 & 0 \\
\hline II. & Exemple & & & & & \\
\hline 11. & Forms of contrapose & 1 & 0 & 0 & 0 & 0 \\
\hline 12. & Examples of unrelatedparties & 1 & 0 & 0 & 1 & 0 \\
\hline 13. & $\begin{array}{l}\text { Examples } \\
\text { transactionstobesubmitted }\end{array}$ & 1 & 1 & 0 & 0 & 0 \\
\hline IIII. & $\begin{array}{l}\text { Mandatory elements to be } \\
\text { presented }\end{array}$ & & & & & \\
\hline 14. & Name of parent company & 1 & 1 & 1 & 1 & 0 \\
\hline 15. & $\begin{array}{l}\text { The name of the party } \\
\text { thatultimatelycontrols }\end{array}$ & 1 & 1 & 0 & 1 & 0 \\
\hline 16. & $\begin{array}{l}\text { The name of the first parent } \\
\text { company that prepares } \\
\text { consolidated financial statements }\end{array}$ & 1 & 1 & 1 & 1 & 1 \\
\hline 17. & $\begin{array}{l}\text { The relationshipbetween a parent } \\
\text { company anditssubsidiaries }\end{array}$ & 1 & 1 & 0 & 1 & 0 \\
\hline 18. & $\begin{array}{l}\text { How to compensate key } \\
\text { management personnel (total and } \\
\text { by category) }\end{array}$ & 1 & 1 & 0 & 1 & 1 \\
\hline 19. & $\begin{array}{l}\text { The nature of the relationship } \\
\text { with affiliated parties }\end{array}$ & 1 & 1 & 0 & 1 & 0 \\
\hline
\end{tabular}

Table 2. Accounting Harmonization - Affiliated Party Regulations 


\begin{tabular}{|l|l|c|c|c|c|c|}
\hline 20. & $\begin{array}{l}\text { Value of related party } \\
\text { transactions }\end{array}$ & 1 & 0 & 1 & 0 \\
\hline 21. & $\begin{array}{l}\text { The value of therelatedparties' } \\
\text { outstandingbalances }\end{array}$ & 1 & 1 & 1 & 1 & 1 \\
\hline 22. & $\begin{array}{l}\text { Termsandconditions of } \\
\text { transactionswithaffiliatedparties }\end{array}$ & 1 & 1 & 0 & 1 & 0 \\
\hline 23. & $\begin{array}{l}\text { Provisions for doubtfuldebts / } \\
\text { related party expenses }\end{array}$ & 1 & 1 & 0 & 0 & 0 \\
\hline 24. & $\begin{array}{l}\text { Submission of information } \\
\text { separately, by types of related } \\
\text { parties }\end{array}$ & 1 & 1 & 1 & 0 & 0 \\
\hline 25. & $\begin{array}{l}\text { Economicsprevalence over the } \\
\text { legal }\end{array}$ & 1 & 0 & 1 & 0 \\
\hline Score & $\mathbf{2 5}$ & $\mathbf{2 3}$ & $\mathbf{6}$ & $\mathbf{1 8}$ & $\mathbf{3}$ \\
\hline
\end{tabular}

Source: Author's projection

In the previous table, I marked with 1 the existence of the element in regulation and 0 , its absence.

Starting from the formula below, we will replace the unknowns and calculate the Jaccard coefficients.

$$
J(A, B)=\frac{|A \cap B|}{|A \cup B|}=\frac{|A \cap B|}{|A|+|B|-|A \cap B|}
$$

J1 (IAS24, OMFP1802) $=23 / 25=0,92$

D J1 (IAS24, OMFP1802) $=2 / 25=0,08$

J2 $($ IAS24, OMFP2844) $=6 / 25=0,24$

D J2 (IAS24, OMFP2844) $=19 / 25=0,76$

J3(IAS24, OMFP3055) $=18 / 25=0,72$

D J3(IAS24, OMFP3055) $=7 / 25=0,28$

J4(IAS24, OMFP1286) $=3 / 25=0,12$

D J4(IAS24, OMFP1286) $=22 / 25=0,88$

Table 3. Situation of Jaccard coefficients

\begin{tabular}{|l|l|l|}
\hline \multirow{2}{*}{ National regulation } & JACCARD COEFFICIENT \\
\cline { 2 - 3 } & J & $\mathrm{D} \mathrm{j}$ \\
\hline OMFP 1802/2014 & 0,92 & 0,08 \\
\hline OMFP 2844/2016 & 0,24 & 0,76 \\
\hline OMFP 3055/2009 & 0,72 & 0,28 \\
\hline OMFP 1286/2012 & 0,12 & 0,88 \\
\hline
\end{tabular}

Source: Author's projection

As shown in the table above, the degree of formal accounting harmonization between OMFP $1802 / 2014$ and IAS24 is 92\%; disimilarities representing only $8 \%$. These weights are a favorable aspect, referring to the degree of formal harmonization between OMFP 3055/2009 for the approval of Accounting Regulations compliant with European directives (predecessor to OMFP 1802/2014) and IAS 24, where there were similarities of $72 \%$.

Concerning OMFP 2844/2016, the level of formal harmonization is only 24\%; $76 \%$ being disimilitidines. In the latter case, the results illustrate a paradox as, since Order 2844/2016 provides for the approval of the Accounting Regulations in line with International Financial Reporting Standards, it was expected that the level of formal alignment between this Standard and IAS 24 would be much picked up. However, it is worth noting that the degree of harmonization between this order 
and IAS 24 has increased, compared to the $12 \%$ achieved compared to the previous order, namely OMFP $1286 / 2012$.

A relevant justification for this situation could be the fact that the legislator assumed that, when drawing up the financial statements, the persons obliged to apply the provisions of the IFRS will also take into consideration the full text of the international accounting standards; the reason for which in order 2844/2016 only the most important aspects were foreseen, and for the rest, referring directly to the standards.

\section{Conclusions}

In present, groups of societies represent a difficult to neglect reality that is of major importance for the economy.

The impact of transactions between affiliated parties on the business itself is significant, given the benefits it can generate if it is carried out in good faith.

Using the Jaccard index as an analysis tool, there was a high degree of similarity between national and international legislation.

Regarding the legislation on affiliated parties, this is an aspect that should not be neglected, namely that national legislation is taken over from international standards and shows a certain degree of dispersion in several regulations. Therefore, not only a review, but also a substantiation, is required.

\section{References}

1. Anghelache Marian, Tranzacţiile între părţi afiliate, risc împărţit între entitate, auditor şi investitor, Practici de audit, nr.4/2017, pag.22

2. Chiș Gavril, Consolidarea situațiilor financiare- Suport de curs, 2005

3. Corlaciu Alexandra, Tiron Tudor Adriana, (2013), "Research on the Perception of Professionals in Romania in the Field of Finance and Accounting Related to Specific Aspects of Transfer Pricing", Revista CAFR, Nr. 1, 2014, pag. 11

4. Gheorghiu Anda, Keiretsu - Modelul Japonez care sfidează criza, Revista Facultatății de Management București, Martie 2013

5. Jerzy Grabowiecki- Financial structure and organization of keiretsu - japanese business groups, 2006

6. Joffre P., Comprendre la mondialisation de l'entreprise, Ed. Economica, 1994, Paris, pag. 72

7. Raffegeau J. și colectiv, Comptes consolides, Editions Fr. Lefebvre, Paris, 1989, pag.17

8. Săcărin Marian et al., Evoluția contabilității românești după 1989 -repere cronologice, 2013

9. Tiron Tudor Adriana et al., Combinări de intreprinderi, Ed. Accent, 2005, Cluj Napoca

10. Tiron Tudor Adriana, Necesitatea armonizării reglementării românești privind prețurile de transfer cu reglementările europene, 2006

11. Vlad Mariana, Note de curs Contabilitatea grupurilor de societăți, 2011

12. Wachowska Małgorzata, The importance of japanese keiretsu groups for knowledge spillovers, Editura Wrocław, 2012

13. IAS 24 - Prezentarea informațiilor privind părțile afiliate

14. Legea contabilităţii 82/1991, în vigoare de la 1 ianuarie 1992, republicată în Monitorul Oficial al României, Partea I, nr. 629 din 26 august 2002

15. Legea $227 / 2015$ privind Codul fiscal

16. OMFP 1802/2014 pentru aprobarea Reglementărilor contabile privind situaţiile financiare anuale individuale şi situaţiile financiare anuale consolidate, publicat în M.O. nr. 963 din 30 decembrie 2014 
17. OMFP 2844/2016 pentru aprobarea Reglementărilor contabile conforme cu Standardele Internaţionale de Raportare Financiară, publicat în M.O. nr.1020 din 19 decembrie 2016

18. OMFP 3055/2009 pentru aprobarea Reglementărilor contabile conforme cu directivele europene, publicat în Monitorul Oficial al României, Partea I, nr.766 din 10 noiembrie 2009

19. OMFP 1286/2012 pentru aprobarea Reglementărilor contabile conforme cu Standardele internaționale de raportare financiară, aplicabile societăților comerciale ale căror valori mobiliare sunt admise la tranzacționare pe o piață reglementată, publicat în Monitorul Oficial nr. 687 din 4 octombrie 2012

20. https://www.iasplus.com/en/standards/ias/ias24 accesat în data de 10.01.2018

21. http://www.finacogrup.ro/dosarpreturidetransfer/?gclid=CjwKCAjwk9HWBRApEiwA6mKWa ZvPo5EIUtuWpbqJik1rCJNz3zDy1_3_ftLIKo7us9Yp2d6us-hJjhoC5JoQAvD_BwE

22. https://www.iasplus.com/en/standards/ias/ias24\#link1

23. https://www.transferpricing.ro/vreau-dosarul-preturilor-de-transfer/ce-este-dosarul-preturilorde-transfer

24. https://www.juridice.ro/499197/tranzactiile-cu-persoane-afiliate-determinarea-preturilor-detransfer-\%C8\%8Bn-lumina-jurisprudentei-actuale.html

25. https://ro.wikipedia.org/wiki/Standarde_Interna\%C8\%9Bionale_de_Raportare_Financiar\%C4 $\% 83$

26. http://www.creeaza.com/afaceri/economie/contabilitate/Sistemul-contabil-din-Romania765.php

27. https://en.wikipedia.org/wiki/Jaccard_index

28. https://www.cafr.ro/uploads/AF\%201\%202014-5e94.pdf\#page=13

29. https://www.gfmag.com/magazine/november-2016/risky-juggling-act

30. http://contabilul.manager.ro/a/9087/contautil-operatiunile-contabile-intre-societati-afiliate.html

31. https://www.scribd.com/document/143057705/1-Abordari-Teoretice-grup-de-Societati

32. http://www.taxwise.ro/servicii/preturi-de-transfer/\#1476605385798-db6cdc09-88f3

33. https://www.ziuacargo.ro/articole/structura-de-tip-holding 